\title{
Stay True, But Innovate!
}

\author{
Anne-Laure Mention \\ anne-laure.mention@rmit.edu.au | RMIT University, Australia \\ João José Pinto Ferreira \\ jjpf@fe.up.pt | INESC Technology and Science, Faculty of Engineering, University of Porto, Portugal \\ Marko Torkkeli \\ marko.torkkeli@lut.fi | Lappeenranta University of Technology, Finland
}

\section{Editorial}

Were you ever asked by a manager to 'do what you want', where you felt free to innovate? Did it feel like freedom? Maybe you felt encouraged since you could now experiment your idea, but did it mean that your performance was now on the radar? Could you then stay true to your vision or did you feel the need to compromise so that the 'numbers lined up'? Either way, you should know that you are not alone. Arguably, we are in an age of paradox ${ }^{1}$ where simultaneous contradictions are all too common. Innovation paradox arises when "the aggressive pursuit of operational excellence and incremental innovation crowds out the possibility of creating groundbreaking innovations" (Davila \& Epstein, 2014, p.2). Often these contradictions are meaningful on their own merit but when interdependent on each other, they create tensions in economic, social, environmental and ethical decision-making. In previous editorials, we have shared how digital innovations and societal disparity across the world are influencing strategic decisionmaking and shifting the innovation mindset. We now stretch the boundaries by suggesting that paradigms relying on economic trade-offs and shared-value that have shaped conventional organisational strategies are no longer sufficient to guide paradoxical tensions in decision-making. The people, the planet and the organisations around us are changing at an increasing pace. While technology-driven innovations are proliferating across everyday interactions - from identity and financial services to shopping and even funeral services, the interdependencies between the old and new economies are getting blurred and confusing. Let us take for example Amazon,

\footnotetext{
${ }^{1}$ Handy, C.B., 1995. The age of paradox. Harvard Business Press, Boston, Massachusetts.
} 
which is fast emerging as a global leader in retail but has its biggest investment in traditional supermarket chain Whole Foods. Yet another example is Tesla's innovative business model, which is outpacing other automobile manufacturers through vertical and horizontal integration into multiple markets. But the promise of low emission, environmentally-friendly Tesla electric cars relies on cobalt mining - a practice which in its current state would fail by utilitarian ethical traditions and may even make one with a Kantian view cringe for the social impact it is leaving behind in conflict-torn Republic of $\mathrm{Congo}^{2}$. The tough questions and accordingly topics of research in innovation now need to focus on managing these paradoxical tensions. Is it ethical to shift away from the old if new ways call for a compromise on current rationale? If there is a spoken or unspoken rule, what is the tipping point of this innovation ordinance?

No doubt, we are living in an era where various segments of the society are self-identifying themselves as global citizens, promoting equality, fairness and empowerment in the quest for converging progress. Yet, where innovations such as artificial intelligence, FinTech, blockchain technology and machine learning are enabling social change through inclusion, swathes of backoffice, middle management and front-line jobs are at risk. Innovations continue to challenge conventionally presumed hierarchies and business models. For researchers and practitioners alike, engaging in these challenging and demanding conditions requires thinking divergently, yet intensely about the paradoxes in innovation - the knowledge sharing versus knowledge protection, local versus global, exploration versus exploitation and strategic stability versus opportunistic flexibility. This may mean employing methodologies that depart from the objective-subjective dichotomy to explore the real world from a pragmatic lens. One could begin with an argument than it would be prudent for a firm to focus on innovations that help reduce costs and maximise productivity, and then question why most firms do not employ a dedicated innovation office? How do innovative firms and people build, cope with and sustain collaborative innovations despite the challenges of intellectual property rights in collaborative business models? How can mindsets of value-acquisition be balanced with innovative thinking on value creation?

Evidence abounds of the companies that have successfully managed the innovation paradox. IBM and Apple for instance re-invented their product and value propositions after breaking through the status-quo. Nestlé's now multi-billion dollar start-up Nespresso revolutionalised the "coffee culture" by re-imagining coffee-by-the-pod. However, as companies like AltaVista and Research in Motion (the firm behind Blackberry) eventually discovered that while incremental innovation and concentrating on operational excellence to feed existing business models delivers gains in a stable environment, it quickly erodes market share in a disruptive and fast-paced technology enabled environment. For companies like AltaVista and RIM, the question was not about recognising technological shift, it was rather about how to cope with the innovation paradox. If the current structures and value propositions are delivering shareholder returns, when what is the right time to invest in experimentation of the unknown? While both these firms could boast about availability of infrastructure to match the change in patterns, they clearly failed to cross the "valley of death" - the often problematic shift from ideation to product development (Branscomb \& Auerswald, 2001; Markham, Ward, Aiman-Smith \& Kingon, 2010).

To overcome shortcoming in resources and capabilities in crossing the valley of death, most industries are increasingly adopting an open innovation model (Chesbrough, 2006; Spender, Corvello,

\footnotetext{
${ }^{2}$ See http://www.dailymail.co.uk/news/article-4764208/Child-miners-aged-four-living-hell-Earth.html
} 
\& Rippa, 2017), leveraging the contributions of foresight and networks (Calof, Meissnerr, \& Razheva, 2017). Yet, research on managing innovation paradoxes is lacking in combining the upstream and downstream value chains surrounding the focal firm's innovation ecosystem. It needs to be acknowledged through methodological shifts that innovation involves not only the focal firm but also its upstream providers, downstream beneficiaries and complementors (Hanaki \& Owan, 2013). Such a focus would uncover the triggers and driving factors of innovation paradoxes, stretching current firm-level focus to individual-level decision-making tension on one hand, and managing social-interactions at the ecosystem-level on the other. One plausible perspective in this quest is O'Reilly and Tushman's (2013) organisational ambidexterity context. As organisations engage in more open and collaborative strategies, innovation paradox faces new tensions in exploitative and exploratory tasks, in terms of profits, intellectual property and sustainable development. Some real world case studies exist which capture the essence of how managers deal with tensions arising from innovation paradoxes (see Bingham, Furr, \& Eisenhardt, 2014; Zeng, $\mathrm{Hu}$, \& Ouyang, 2017). Yet, research drawing on structural ambidextrous capabilities (see Dobón \& Soriano, 2008), contextual ambidextrous capabilities (see Gibson \& Birkinshaw, 2004) and coordinated ambidextrous capabilities (see Du, Pan, \& Zuo, 2013) seems providential to advance the science and practice of innovation management.

In such a frame, while we reflect on the famous cases of Xerox ${ }^{3}$ and Kodak ${ }^{4}$ in understanding why some firms fails to innovate, Kalling (2007) point towards commonalities in organisational learning and knowledge creation as enablers of innovation whilst insufficient readiness, risk aversion mindset and ineffective team-working environment as factors which may stifle innovation. If resistance to innovation is rooted in paradoxes affecting active and passive engagement, then there great value for society in empirically testing and documenting structural, emotional and psychological conditions in which innovation fails, thrives or simply tires out. We can learn more about how to stay 'true' and yet innovate by choosing more pragmatically grounded methodologies, entrenching research into how individuals, firms and the ecosystems manage innovation paradoxes.

Anne-Laure Mention, João José Pinto Ferreira, Marko Torkkeli

Editors

\section{References}

Bingham, C. B., Furr, N. R., \& Eisenhardt, K. M. (2014). The opportunity paradox. MIT Sloan Management Review, 56(1), p.29.

Branscomb, L.M. and Auerswald, P.E., 2001. Taking technical risks: How innovators, managers, and investors manage risk in high-tech innovations. Cambridge, MA, USA: MIT Press.

\footnotetext{
${ }^{3}$ See https://www.strategy-business.com/article/9854?gko $=3 a 579$

${ }^{4}$ See https://hbr.org/2016/07/kodaks-downfall-wasnt-about-technology
} 
Calof, J., Meissner, D. and Razheva, A., 2017. Overcoming open innovation challenges: A contribution from foresight and foresight networks. Technology Analysis \& Strategic Management, pp.1-16.

Chesbrough, H.W., 2006. The era of open innovation. Managing innovation and change, 127(3), pp.34-41.

Davila, T. and Epstein, M., 2014. The innovation paradox: Why good businesses kill breakthroughs and how they can change. San Francisco, California: Berrett-Koehler Publishers.

Dobón, S.R. and Soriano, D.R., 2008. Exploring alternative approaches in service industries: The role of entrepreneurship. The Service Industries Journal, 28(7), pp.877-882.

Du, W., Pan, S.L. and Zuo, M., 2013. How to balance sustainability and profitability in technology organizations: An ambidextrous perspective. IEEE Transactions on engineering management, 60(2), pp.366-385.

Gibson, C.B. and Birkinshaw, J., 2004. The antecedents, consequences, and mediating role of organizational ambidexterity. Academy of management Journal, 47(2), pp.209-226.

Hanaki, N. and Owan, H., 2013. Autonomy, conformity and organizational learning. Administrative Sciences, 3(3), pp.32-52.

Kalling, T., 2007. The lure of simplicity: learning perspectives on innovation. European Journal of Innovation Management, 10(1), pp.65-89.

Markham, S.K., Ward, S.J., Aiman-Smith, L. and Kingon, A.I., 2010. The valley of death as context for role theory in product innovation. Journal of Product Innovation Management, 27(3), pp.402-417.

Spender, J.C., Corvello, V., Grimaldi, M. and Rippa, P., 2017. Startups and open innovation: a review of the literature. European Journal of Innovation Management, 20(1), pp.4-30.

Zeng, D., Hu, J., \& Ouyang, T. (2017). Managing Innovation Paradox in the Sustainable Innovation Ecosystem: A Case Study of Ambidextrous Capability in a Focal Firm. Sustainability, 9(11), 2091.

Cite paper as: Mention, A., Pinto Ferreira, J.J., Torkkeli , M., (2018). Stay True, But Innovate! - Editorial, Journal of Innovation Management, www.open-jim.org, 6(1), 1-4. http://hdl.handle.net/10216/111571 